\title{
The prototype of the Greenhouse Smart Control and Monitoring System in Hydroponic Plants
}

\author{
Arif Supriyanto ${ }^{1}$, Fathurrahmani ${ }^{2}$ \\ ${ }^{1,2}$ Program Studi Teknik Informatika, Politeknik Negeri Tanah Laut \\ Jl. Ahmad Yani Km.06 Desa Panggung, Pelaihari, Kalimantan Selatan, telp. 0512-2021065 \\ e-mail: arif@politala.ac.id, fathurrahmani@politala.ac.id
}

\begin{abstract}
This research helps the farmers to do the humidification control and monitor the condition of hydroponic plants in greenhouses in real-time. When it comes to watching the hydroponic plants in greenhouses, the farmers usually experience difficulties because they still do it manually. Activities such as checking the temperature, air humidity, and also water quality in hydroponic plants by coming directly to the greenhouse are still ineffective. Therefore this research aims to make a smart greenhouse prototype for hydroponic plants. Smart greenhouse hardware was built based on the Arduino microcontroller, DHT11 sensor, pH sensor, TDS, DS18b20 temperature, ultrasonic, and esp8266 wifi module. The monitoring system features information on water quality from hydroponic plants and the ability to record farming activities from planting preparation to web-based harvesting. The test results of smart greenhouse monitoring system can display the hydroponic plant conditions and able to do the humidification control with an upper limit of 35 degrees celsius because plant can survive with disease under 35 degrees celsius, with small average offset for the sensor, and an average offset of 1.49 from TDS sensors, with temperature of 0.50 and $p H$ of 0.34 .
\end{abstract}

Keywords: Greenhouse, NFT hydroponics, Humidification, Monitoring System, Arduino

\section{Introduction}

The agricultural production sector is critical, an area that can sustain people's lives. In general, most farmers still use traditional farming systems and are dependent on climate change. Uncertain climate change in recent years has made the timing of harvests difficult for farmers to predict. Prolonged rain increases the risk of pests and diseases, and excessive heat causes the plants to lose a lot of water and wither, resulting in farmers experiencing losses in the form of crop failure. Therefore the existence of a greenhouse in the agricultural world is becoming increasingly important.

The greenhouse is a building intended for the cultivation of plants with several variable settings in it to match the growth and development of plants that are cultivated[1]. The greenhouse cultivation system for farmers is relatively new, and thus some of the farmers still traditionally use this system, i.e., the whole work is always done using human labour such as the air humidity monitoring process, temperature and humidification process, and watering plants in the greenhouse building.

Hydroponic farming is one of the farming methods in a greenhouse building. Hydroponics is an agricultural system that utilises water as a base for the development of the plant body. The water used is not ordinary, but the water that contains nutrients that can help the process of plant growth[2]. In addition to rain that functions as plant nutrition, several environmental factors must be considered, including the humidity and temperature [3]. To 
control the environmental factor, a greenhouse building with this hydroponic farming system in it will be perfect. Nutrient Film Technique (NFT) is a hydroponic cultivation model that places the plant roots on shallow layers (of water). The water is circulated and contains nutrients according to plant needs. In the NFT model plants, nutrition is a critical factor, i.e., the dosage of food given must be precise because either the deficiency or excess of nutrients is intoxicating for the plants and eventually will kill them. Based on research [4] NFT is better than DFT because each hydroponic site only given by one plant.

Given the problems that arise on greenhouses and hydroponics, thus a smart greenhouse prototype was created to be able to monitor the temperature, humidity, and is observed in realtime via a smartphone. The concept of this research has done by previous studies including [5] conducting research that provides automatic nutrient control in hydroponic plants, but the weakness of this study is that it only uses a pH sensor to detect water quality in hydroponics. [6] conducting research that could only monitor the condition of the humidity and the temperature inside the greenhouse. [7] tracking greenhouses using the Zigbee protocol. [8] tracking the situation of the greenhouse by utilising the blynk android platform, but the downside of this research is the limited use of blynk because they have to subscribe to get the full features. [9] internet of things for planting in smart farm hydroponics with the wireless sensor network system. [10] remote monitoring system for hydroponic planting media. [11] intelligent hydroponic farming using telegram messenger.

In contrast to previous studies, this study make a smart greenhouse that is able to control the humidification process by adding a watering system to the air to increase the humidity of the room, in which later all of these systems are going to be controlled automatically by a microcontroller based on the reading of the sensors inside the greenhouse room. For the hydroponic planting method in the greenhouse, the system monitoring is used to determine the quality of water in hydroponics in the form of information on the levels of nutrients dissolved in water, water $\mathrm{pH}$, water temperature, and water level in a hydroponic water storage container. The monitoring system provides features of crop types, crop cycles, and also harvest prediction to help the farmers recording their farming activities, ranging from planting preparation to the harvest phase.

\section{Research Methods}

The focus of this research is creating smart greenhouse prototypes for humidification control and monitoring systems for hydroponic plants using the NFT method. The research flow can see in Figure 1.

The research starts with the problem identification of a smart greenhouse prototype construction. Then, the researchers conduct a data collection with literary studies and interviews to obtain system specifications, i.e., the requirements from the tools used and the software that needs to built. Some of the demands from those tools are the microcontrollers used, i.e., Arduino, temperature and humidity sensors, Total Dissolved Solids (TDS) sensor, $\mathrm{pH}$ sensor, water temperature sensor, ultrasonic pump sensor, relay, Wi-Fi module, and also the requirements to build hydroponics with NFT method. The recommended software is a plant monitoring application that planted inside a smart greenhouse. Then the researchers do the system design. The designing process includes tools design (hardware) and software design. The researchers then implement the system or constructed it, followed by tests and result in an analysis of the smart greenhouse. If the test results show that it is incompatible with the initial requirements, the phase would repeat to the system design, but if it is compatible then the next step is making conclusions, and the research is done. 


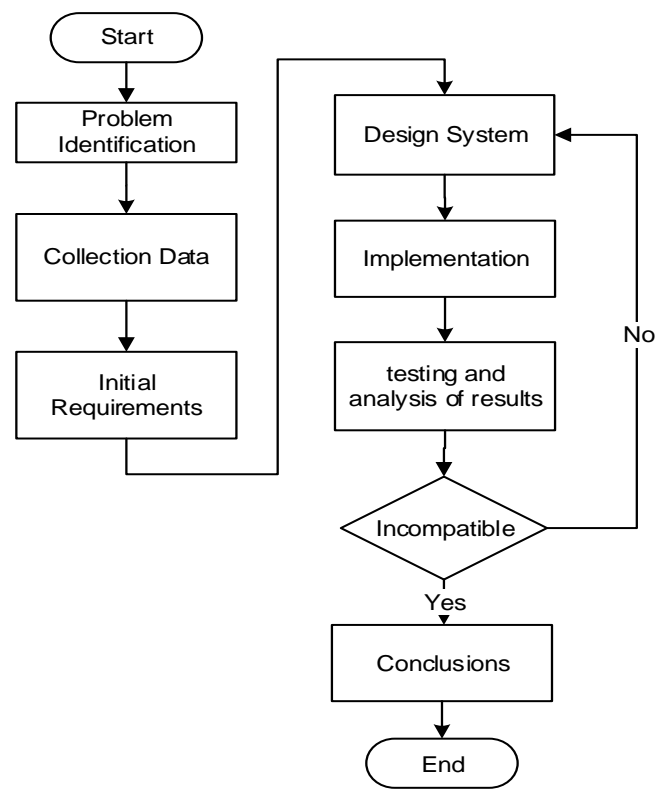

Gambar 1 Research flowchart

\subsection{Research Design}

The smart greenhouse is intended to provide help to farmers in the form of a humidification control system and a monitoring system that can provide information related to environmental and plants conditions in the greenhouse in the way of water level status, $\mathrm{pH}$, water temperature, and water nutrition through smartphone use. The smart greenhouse divided into two parts, which are hardware and software. The humidification control system works when the humidity in the greenhouse starts to deteriorate. When this happens, the watering pump will start automatically to boost the moisture in the room and set the humidity level as befitting. The scheme of the research design can be seen in Figure 2 .

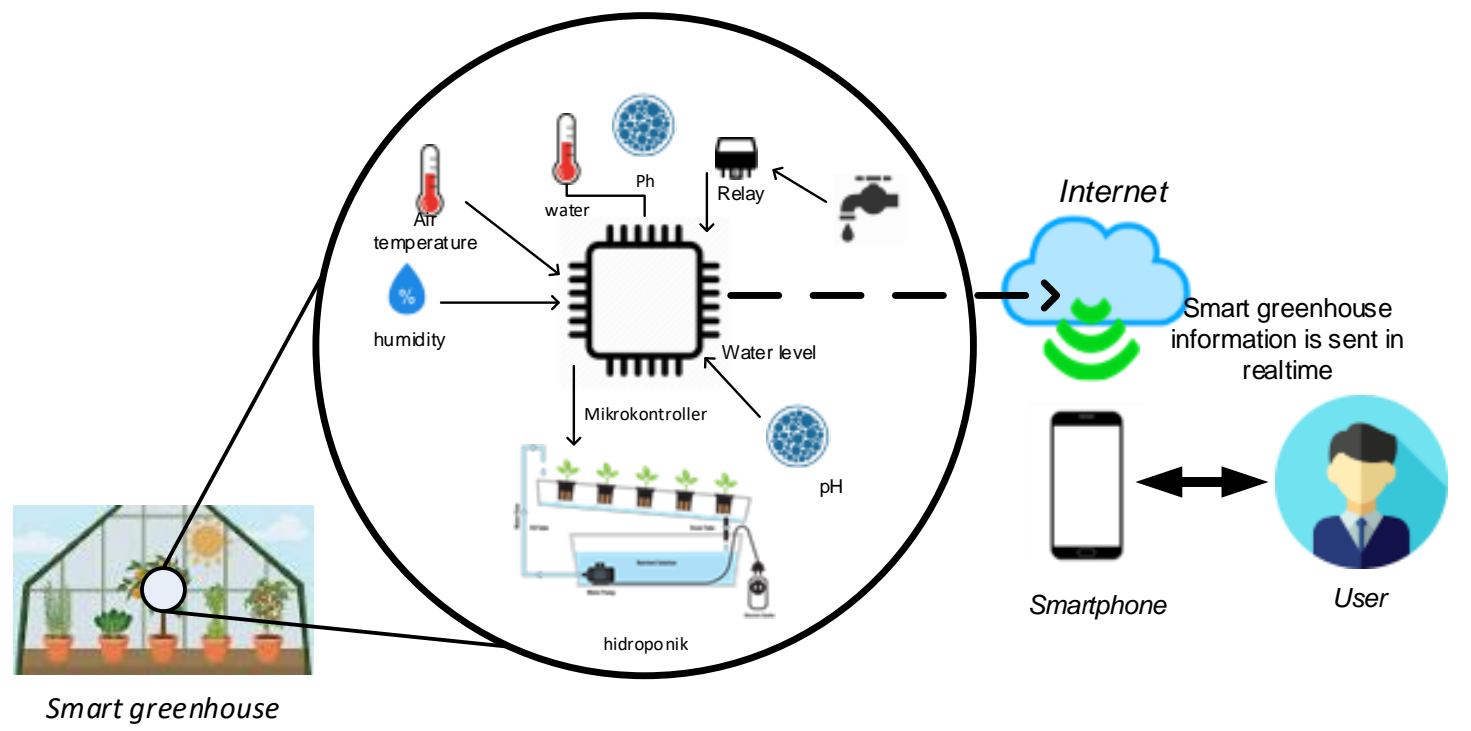

Figure 2. Smart greenhouse system design 


\section{Result and Discussion}

\subsection{Hardware Design}

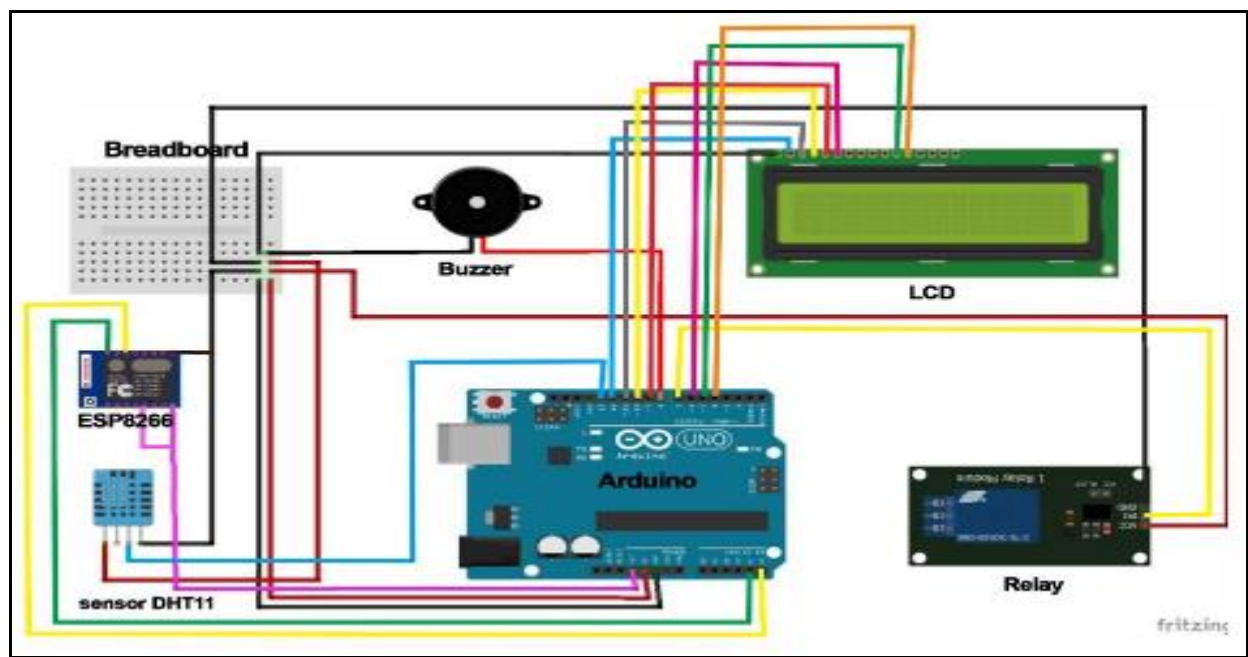

Figure 3. Schematic of a humidification control system

Figure 3 shows the schematic design of the hardware that is used to measure the temperature, humidity and humidification control in a greenhouse. This particular hardware is called DHT11 Sensor with humidity measurement range 20-90\% RH and temperature 0-50 Celcius degrees. It is used to measure temperature and humidity, relay, pump, buzzer, LCD screen and Arduino R3 as a microcontroller.

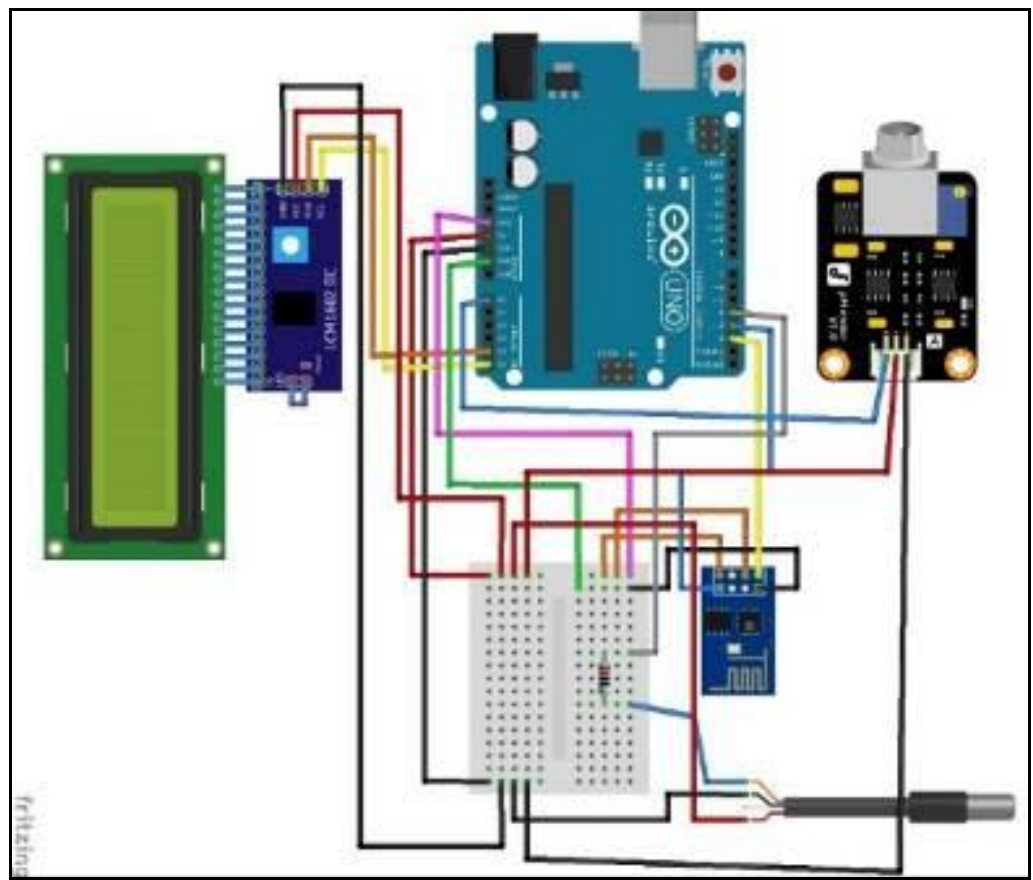

Figure 4. Schematic of a hydroponic monitoring system 
Figure 4 shows a schematic of a hydroponic monitoring system that is used to measure water quality in a hydroponic water reservoir. It uses hardware such as DF Robot analogue water $\mathrm{pH}$ sensor kit, DS18b20 water temperature sensor, TDS meter analogue DF Robot sensor, ultrasonic sensor, esp8266 wifi module, LCD screen, and Arduino as a microcontroller.

\subsection{Program Flowchart}

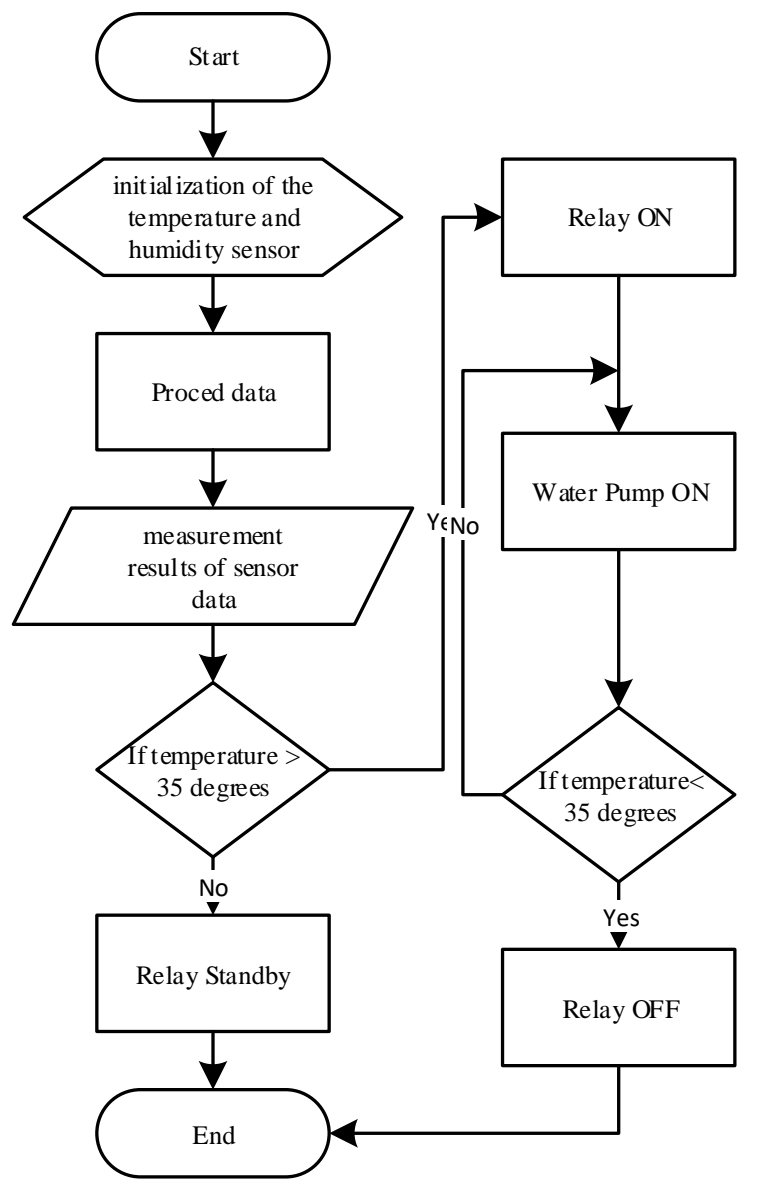

Figure 5. Flowchart of the humidification control program

Figure 5 shows the humidification control process of the greenhouse. The process begins with the initialisation of the temperature and humidity sensor of the air, then proceed with the process of sensor data reading by the microcontroller. The measurement results of sensor data that have been processed by the microcontroller then displayed on the LCD screen. The next process is determined when the temperature sensor result shows an exceeding result of a predetermined threshold. If the temperature is above 35 degrees, the microcontroller will command the relay to start the water pump so that the greenhouse room temperature can be adjusted back to normal. This humidification process will continue until the room temperature returns below 35 degrees. 


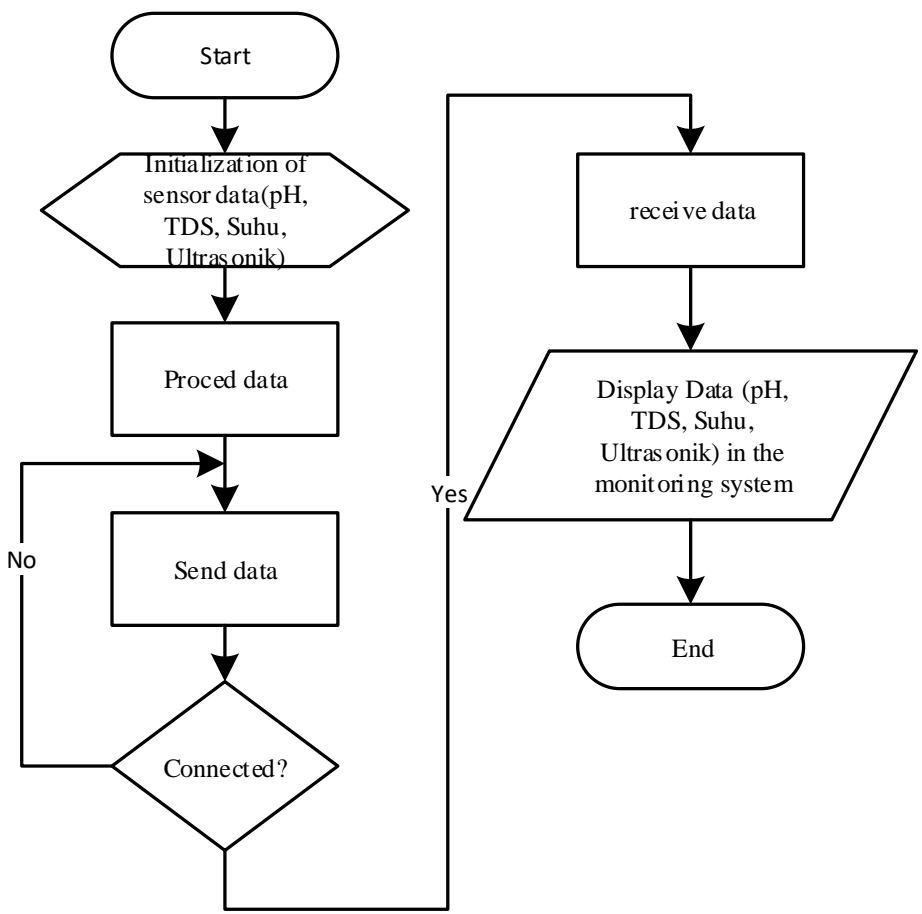

Figure 6. Flowchart of a hydroponic monitoring program

Figure 6 shows the flow of the process of sensor data distribution up until the sensor data display in the water monitoring system in hydroponics. The process begins with the initialisation of sensor data and then proceed with the process of sensor data reading by the microcontroller. After the sensor data reading process is complete, proceed with the sensor data distribution process using the wifi module, followed by a condition of connection checkup, if it is connected, the monitoring system will receive data from the sensor reading made by the microcontroller, but if it is not connected, the process of sensor data distribution will repeat again. After the sensor data is received, this data will be directly displayed in the monitoring system in real-time according to the sensor readings.

\subsection{Software Design}

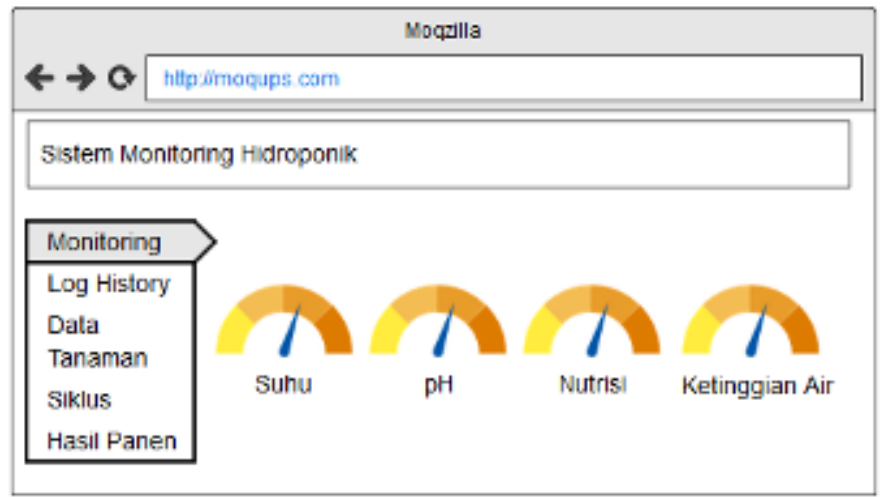

Figure 7. The interface design of the hydroponic plant monitoring 
Figure 7 shows the interface design of a monitoring system on a hydroponic plant. There are several menus in this interface; the monitoring menu is used to display the gauge indicator from the value of sensor readings in the hardware section, the plant data menu is used to determine the types of plants that exist in hydroponics, the cycle menu is used to determine the number of plants to be planted and also the cycle of the plants from the beginning of planting to harvest time, and the harvest result prediction menu is used to calculate the harvesting result per kilogram.

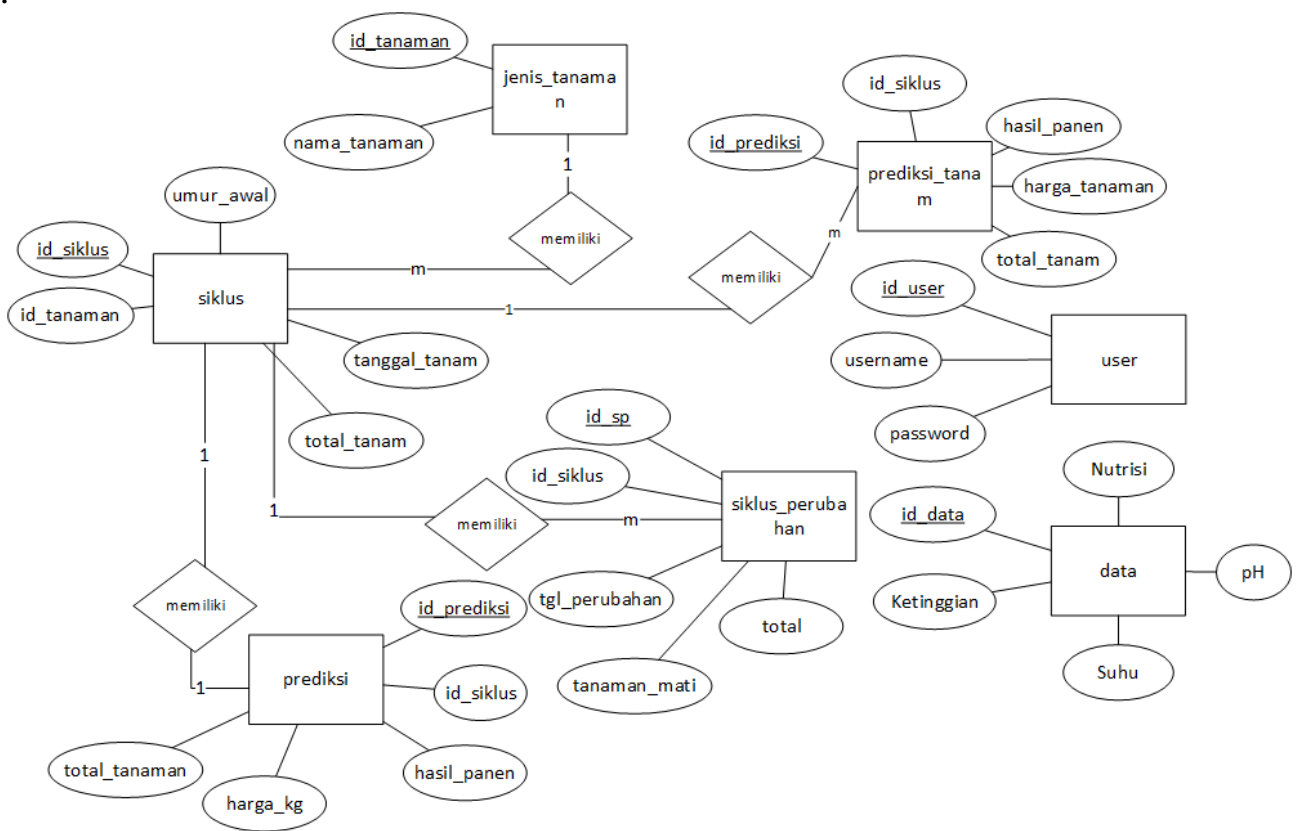

Figure 8. ERD (Entity Relationship Diagram) Design

Figure 8 shows the ERD design that is used to design a greenhouse monitoring system database. Seven entities used in the ERD design, and they are user entity, data, plant_type, cycle, prediction, cycle_change, and plant_prediction.

\subsection{Hardware Implementation}

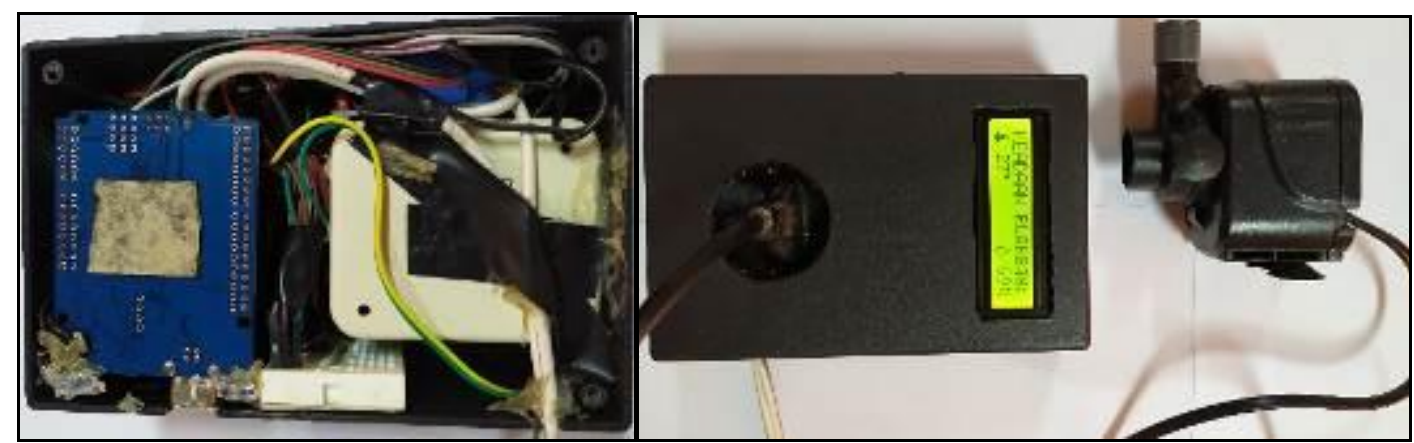

Figure 9. Implementation of a humidification control system tool in a greenhouse

Figure 9 shows the results of the humidification control system implementation. There is a DHT 11 sensor that is used in this tool to measure temperature and humidity, relay, water pump and an LCD screen which is intended to provide information about the temperature and 
humidity of greenhouse room. The water pump will start automatically if the room temperature exceeds a predetermined threshold of 35 degrees.

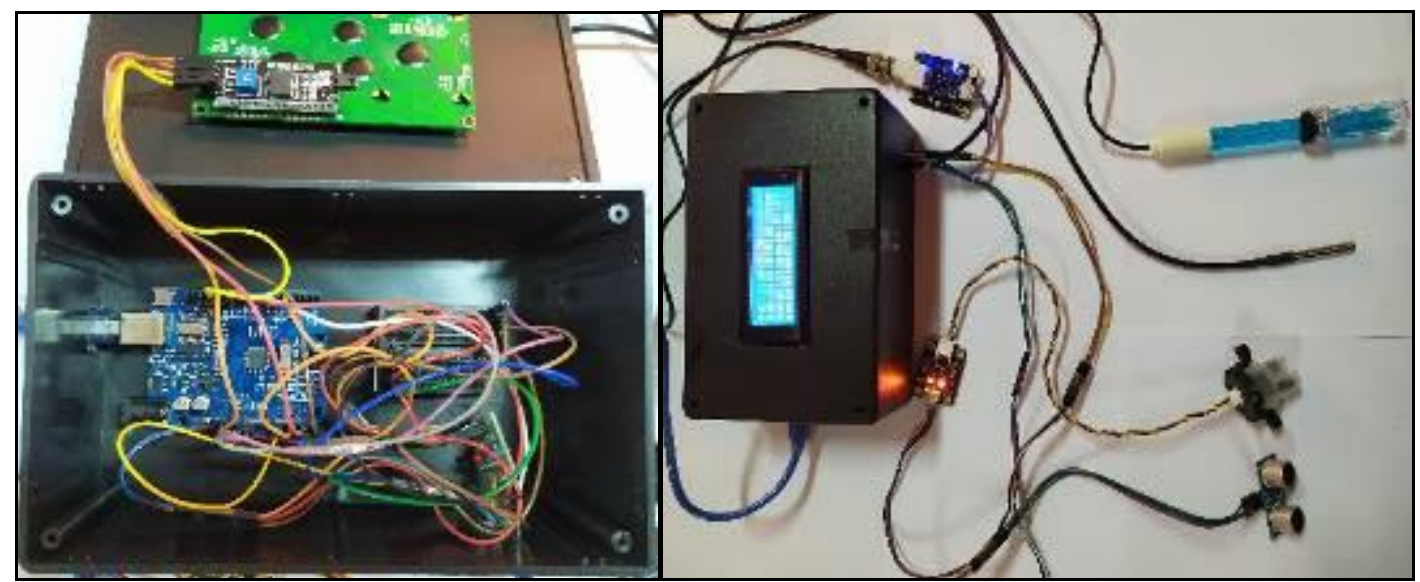

Figure 10. Implementation of monitoring tool on hydroponic plants

Figure 10 shows the implementation results of the hydroponic quality monitoring water hardware. There are $\mathrm{pH}$ sensor, temperature, and TDS sensor in this tool that can measure water quality in hydroponics and ultrasonic sensors used to measure the height of a water reservoir. Sensor readings that have been processed by the microcontroller can be displayed via the LCD screen and sent to the monitoring system interface through the WiFi module.

Figure 4.8 shows the implementation results from the hardware of the water quality monitoring system in hydroponics. There are several sensors In this tool that can measure water quality in hydroponics. Sensor readings that have been processed by the microcontroller can be displayed via the LCD screen and sent to the monitoring system interface through the WiFi module.

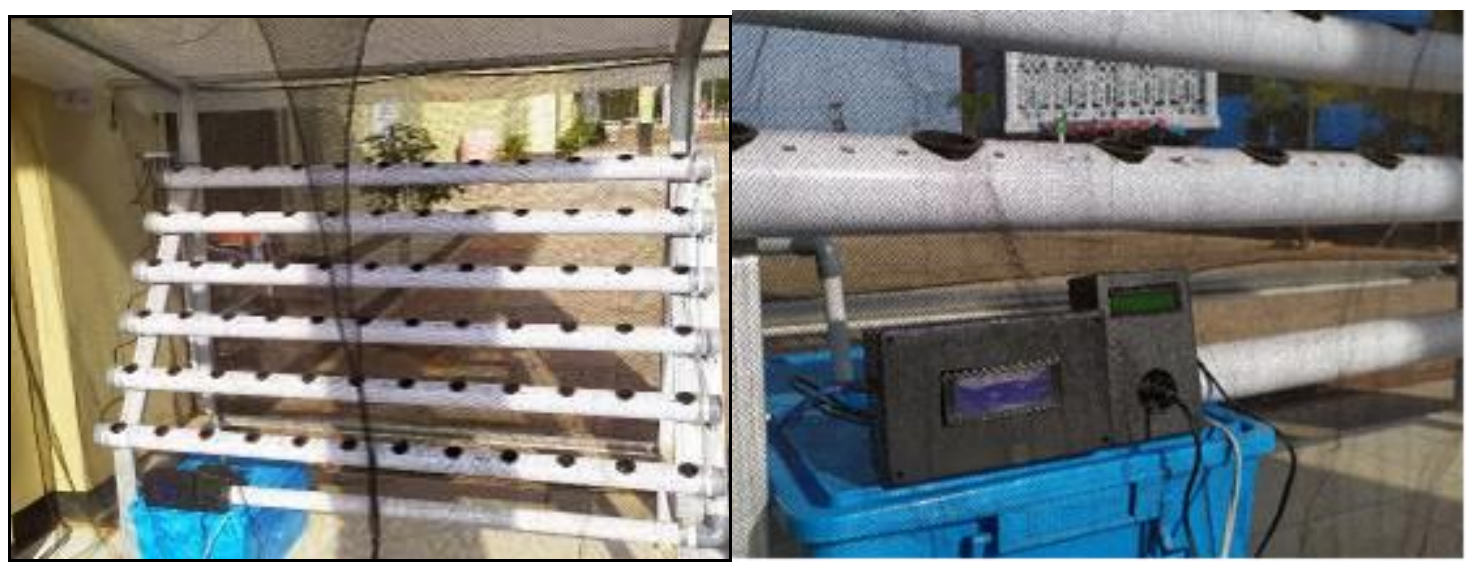

Figure 11. The smart greenhouse implementation

A prototype of a greenhouse is made specifically for this research, with the following specifications: the dimension is $250 \times 120$ centimetres, using UV plastic 14200 microns for the top cover, and using insect mesh 40 for the walls. As for the hydroponics, the dimension is 200x 100 centimetres, with six levels, and 72 net pots with NFT (Nutrient Film Technique) nutritional system. 


\subsection{Software Implementation}

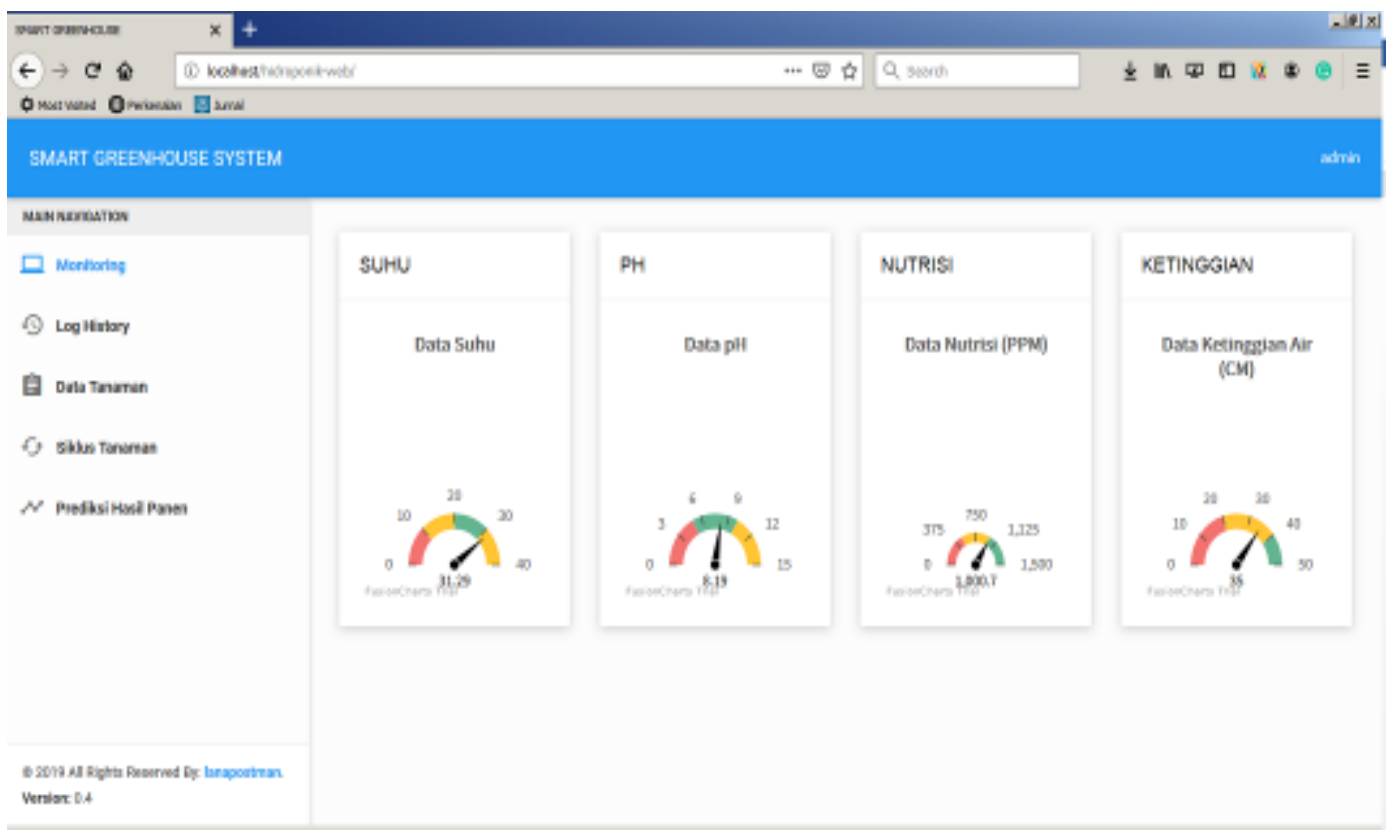

Figure 12. Implementation of a smart greenhouse monitoring system

Figure 12 shows a water quality monitoring system on hydroponics in a greenhouse. The monitoring menu shows some information such as the temperature gauge, $\mathrm{pH}$, nutrition, and altitude that provided in the form of results value from the sensor readings contained in the hardware.

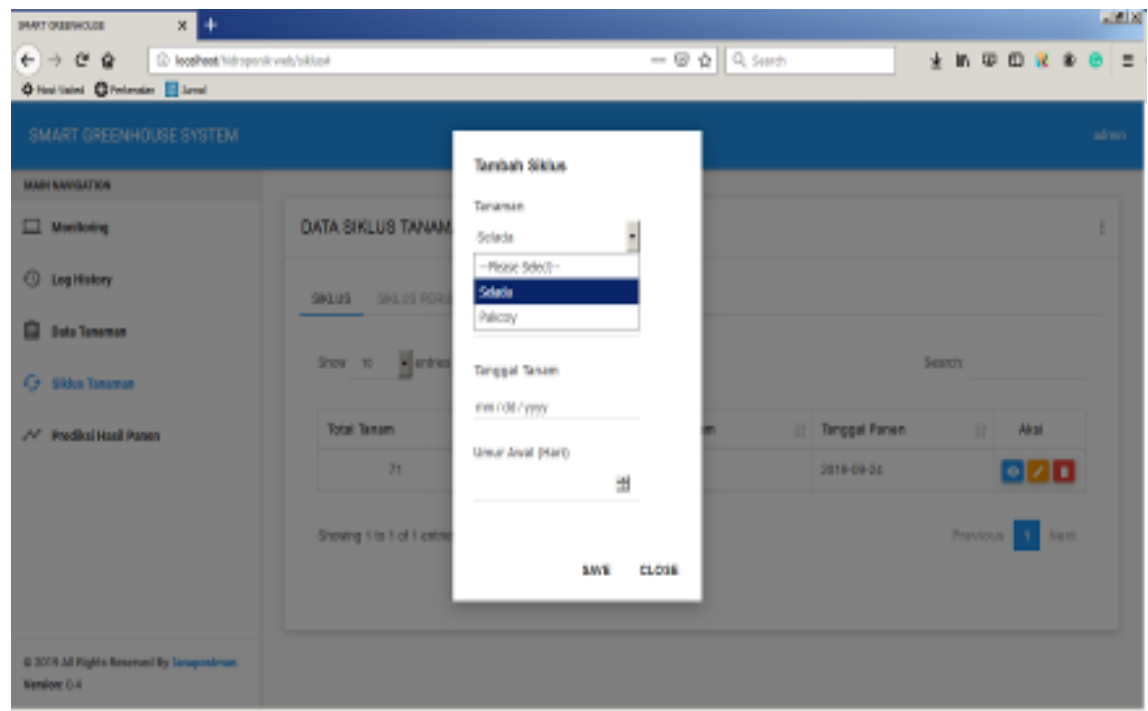




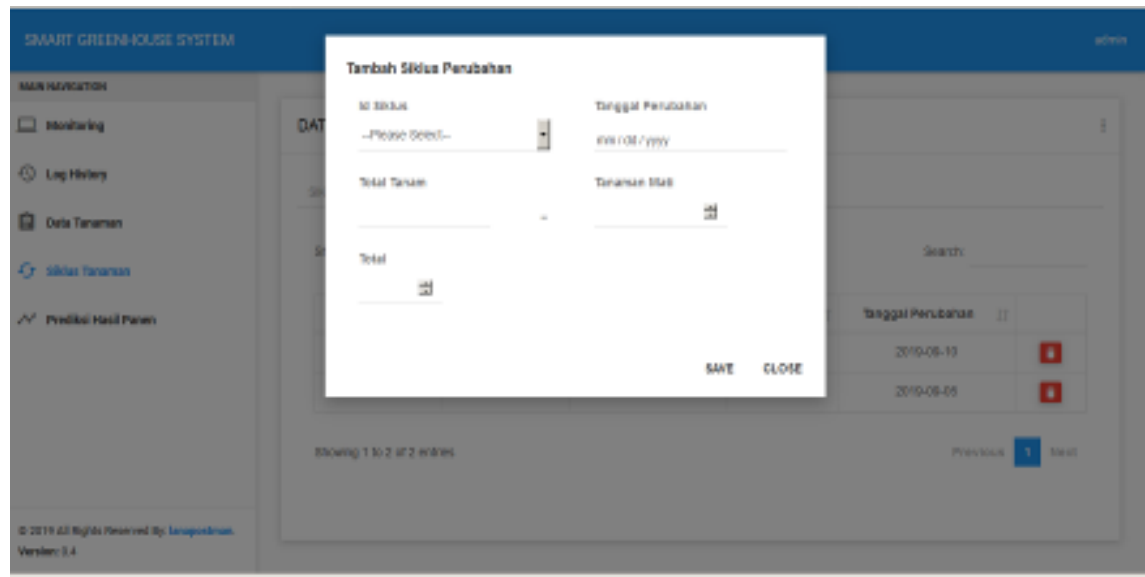

Figure 13. Added crop cycle data menu

User can add plants, planting dates, and the age of the plants in the crop cycle menu. This menu also provides information on total planting data, type of plant, planting date, and harvest prediction date, which automatically filled by planting date and type of plant. The change cycle menu section also provides a feature to input data that can be used by users to make changes to the crop cycle if there are dying plants.

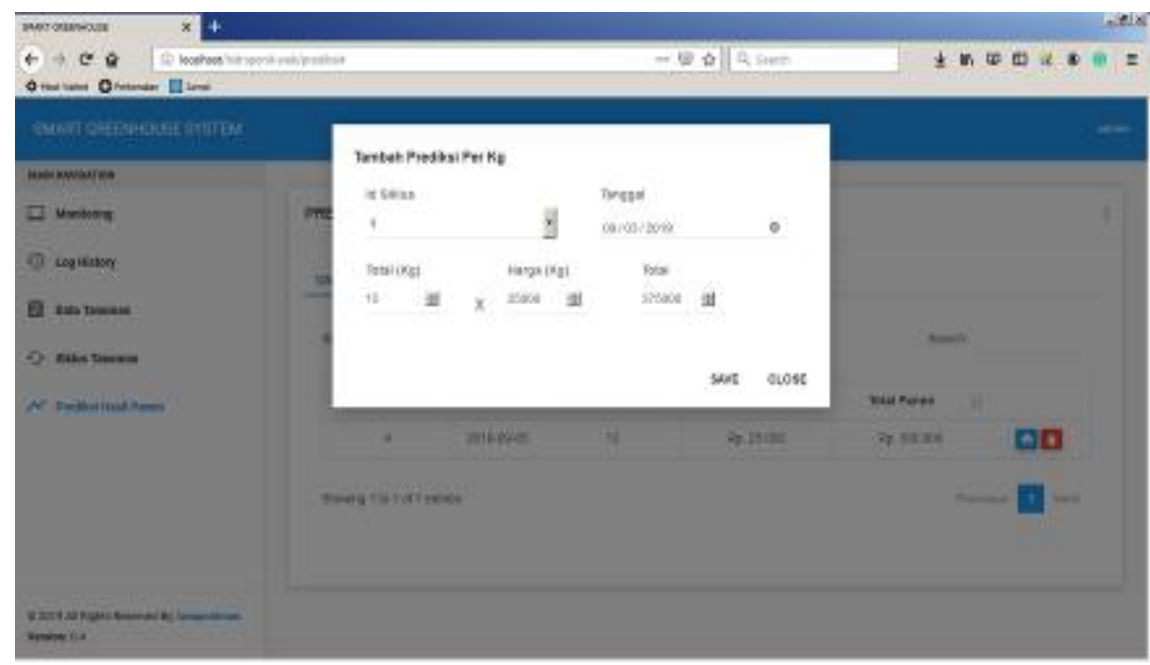

Figure 14. Harvest prediction menu

\subsection{Smart Greenhouse Testing}

This testing aims to determine the performance of smart greenhouse system and to see if it is functioning correctly and by the system specifications that have planned. The test includes the accuracy of the hardware refer to table $1,2,3,4$ and functionality of the software used. The test results will be analysed and used by the researchers to conclude the study.

\subsubsection{Humidification Control Testing}

Humidification control testing is carried out to determine whether the water pump will work accordingly with the results of the temperature and humidity sensor readings. The result of water pump control test can be seen in Table 1 . 
Table 1. Water pump control test

\begin{tabular}{|c|c|c|c|}
\hline Test & $\begin{array}{c}\text { Temperature } \\
\left({ }^{\circ} \mathbf{C}\right)\end{array}$ & Humidity (RH) & Pump \\
\hline 1 & 37 & 64 & ON \\
\hline 2 & 39 & 58 & ON \\
\hline 3 & 28 & 80 & OFF \\
\hline 4 & 36 & 69 & ON \\
\hline 5 & 29 & 89 & OFF \\
\hline
\end{tabular}

From table 1, it can conclude that the pump would start working and watering the air when the ambient temperature in the smart greenhouse is above 35 degrees and will stop when the temperature drops below 35 degrees.

\subsubsection{Sensor Accuracy Testing}

A sensor accuracy testing is carried out to determine the accuracy of the sensor readings used with comparator equipment to obtain sensor measuring devices that have high efficiency and excellent precision. TDS sensor testing can be seen in Table 2.

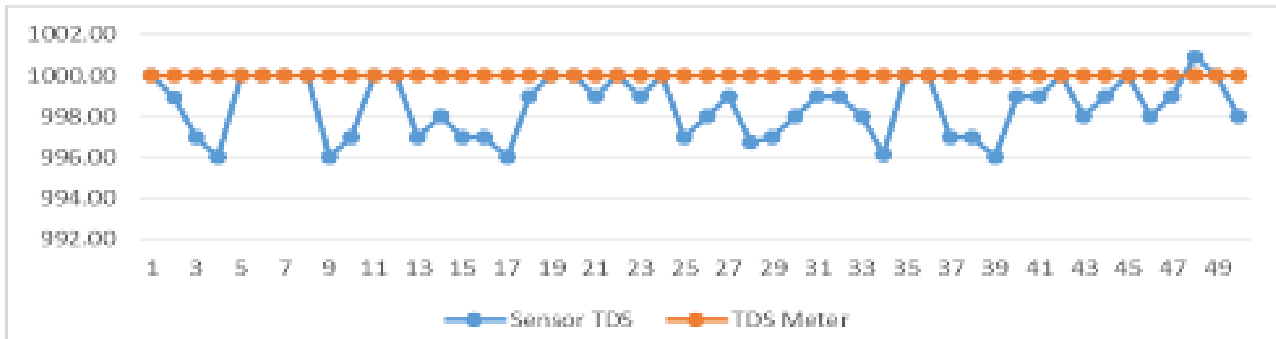

Figure 15. Comparison graph of TDS sensor testing

Table 2. TDS DF Robot sensor testing with TDS Meter

\begin{tabular}{|c|c|c|c|}
\hline \multirow{2}{*}{$\begin{array}{c}\text { TDS } \\
\text { Meter } \\
(\text { PPM) }\end{array}$} & \multicolumn{2}{|c|}{ TDS DF Robot (PPM) } & $\begin{array}{c}\text { Average } \\
\text { Difference }\end{array}$ \\
\hline 1000 & 1000.90 & Maximum & Minimum \\
\hline
\end{tabular}

The result of the TDS sensor test table above shows there is a difference between measurements using a TDS meter with a measured value. In PPM 1000 there is an offset value of 1000.90 for the maximum value and 996.12 for the minimum amount, with an average offset for 50 sample data is 1.49 .

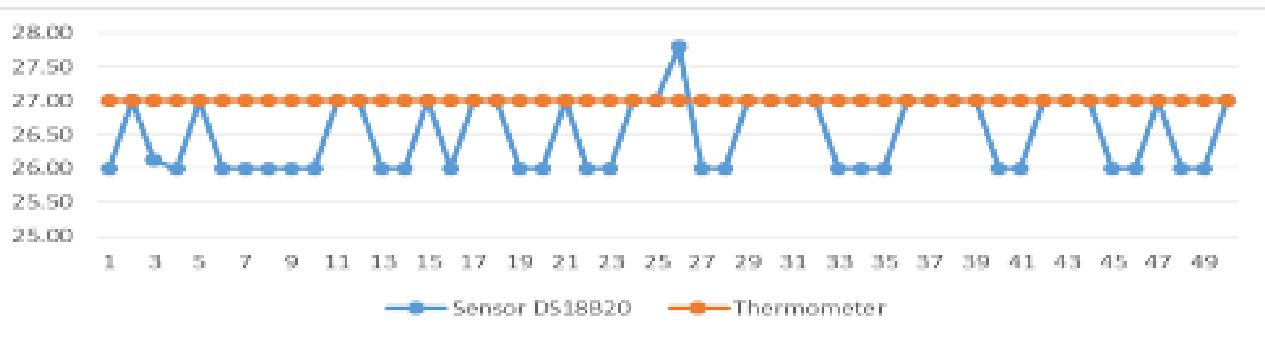

Figure 16. Comparison graph of water temperature sensor testing 
Table 3. The DS18B20 water temperature sensor testing

\begin{tabular}{|c|c|c|c|}
\hline \multirow{2}{*}{ Thermometer } & \multicolumn{2}{|c|}{ DS18B20 $\left({ }^{\circ} \mathbf{C}\right)$} & $\begin{array}{c}\text { Average } \\
\text { Difference }\end{array}$ \\
\cline { 2 - 3 } & Maximum & Minimum & 0.50 \\
\hline 27 & 27.81 & 26.12 & \\
\hline
\end{tabular}

From the results of the DS18B20 sensor test table, there is a difference between measurements using a thermometer with a measured value. At the temperature of 27 degrees, there is an offset value of 27.81 for the maximum value and 26.12 for the minimum amount, with an average offset for 50 sample data is 0.50 .

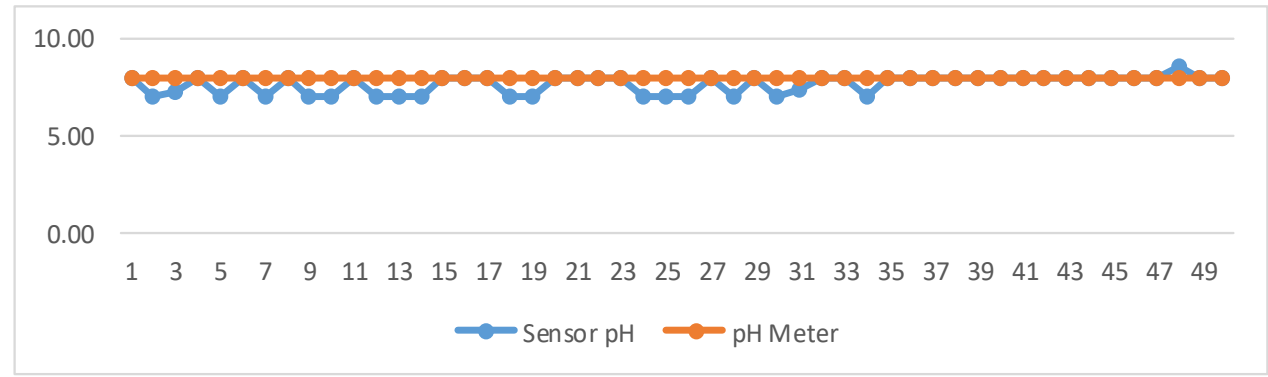

Figure 17. Comparison graph of water $\mathrm{pH}$ sensor testing

Table 4. The DF Robot $\mathrm{pH}$ sensor testing

\begin{tabular}{|c|c|c|c|}
\hline \multirow{2}{*}{ PH Meter } & \multicolumn{2}{|c|}{ pH DF Robot } & $\begin{array}{c}\text { Average } \\
\text { Difference }\end{array}$ \\
\cline { 2 - 3 } & Maximum & Minimum & 0.34 \\
\hline 8 & 8.58 & 7.32 & 0.32 \\
\hline
\end{tabular}

The results of the DF Robot $\mathrm{pH}$ sensor testing table indicates a difference between measurements using a $\mathrm{pH}$ Meter with a measured value. On the $\mathrm{pH}$ meter 8 there is an offset value of 8.58 for the maximum value and 7.32 for the minimum amount, with an average offset for 50 sample data is 0.34 .

\section{Conclusion}

1. The output of this research is a prototype of a smart greenhouse for hydroponic plants that can control humidification with an upper-temperature limit of 35 degrees celsius.

2. A smart greenhouse monitoring system can monitor the condition of hydroponic plants, including water temperature conditions, water $\mathrm{pH}$, nutrition and water level in water reservoirs.

3. According to the results of sensor testing, the sensors used in making smart greenhouses shows good accuracy. The sensor has a small average offset; the TDS sensor obtains an average offset of 1.49 and a temperature of 0.50 and a $\mathrm{pH}$ of 0.34 .

\section{Acknowledgements}

This research funded by the Directorate of Research and Community Service from the Ministry of Research, Technology, and Higher Education, by the Ministry decree of 043/SP2H/LT/DRPM/2019. 


\section{Reference}

[1] M. Srbinovska, C. Gavrovski, V. Dimcev, A. Krkoleva, and V. Borozan, "Environmental parameters monitoring in precision agriculture using wireless sensor networks," $J$. Clean. Prod., 2015.

[2] f. Hadiatna and r. Susana, "Rancang Bangun Smart pH Meter Sebagai Alat Ukur Pemantau Larutan Nutrisi," ELKOMIKA J. Tek. Energi Elektr. Tek. Telekomun. Tek. Elektron., 2019.

[3] A. Alshrouf, "Hydroponics, Aeroponic and Aquaponic as Compared with Conventional Farming," Am. Sci. Res. J. Eng. Technol. Sci., 2017.

[4] R. Nirmalasari and Fitriana, "Perbandingan Sistem Hidroponik Antara Desain Wick (Sumbu) Dengan Nutrient Film Technique (NFT) Terhadap Pertumbuhan Tanaman Kangkung Ipomoeaaquaticadan Lingkungan,” Ilmu Alam dan Lingkung., 2019.

[5] A. B. Pradana, "Rancang Bangung Sistem Kontrol Air Bernutrisi Pada Sistem NFT Hindroponik Tanaman Selada Berbasis Mikrokontroler," J. Electr. Eng., 2017.

[6] Q. Syadza, A. G. Permana, and D. N. Ramadan, "Pengontrolan dan Monitoring Prototype Greenhouse Menggunakan Mikrokontroler dan Firebase," proceeding Telkom Univ. Open Libr., 2018.

[7] J. Li, "Design and realisation of greenhouse sensor intelligent management system based on the internet of things," Int. J. Online Eng., 2017.

[8] N. Hidayati et al., "Prototype smart home dengan modul nodemcu esp8266 berbasis internet of things (IoT)," Tek. Inform. Univ. Islam Majapahit, 2018.

[9] J. Pitakphongmetha, N. Boonnam, S. Wongkoon, T. Horanont, D. Somkiadcharoen, and J. Prapakornpilai, "Internet of things for planting in smart farm hydroponics style," in 20th International Computer Science and Engineering Conference: Smart Ubiquitous Computing and Knowledge, ICSEC 2016, 2017.

[10] B. Siregar, S. Efendi, H. Pranoto, R. Ginting, U. Andayani, and F. Fahmi, "Remote monitoring system for hydroponic planting media," in 2017 International Conference on ICT for Smart Society, ICISS 2017, 2018.

[11] R. E. N. Sisyanto, Suhardi, and N. B. Kurniawan, "Hydroponic smart farming using cyber-physical social system with telegram messenger," in 2017 International Conference on Information Technology Systems and Innovation, ICITSI 2017 Proceedings, 2018. 